\title{
Biopolitics and Pain: Approximations between Foucault and Lacanian Psychoanalysis
}

\author{
Carla Oliveira Fernandes - Universidade Federal do Rio de Janeiro, Rio de Janeiro, Brasil \\ Clándio Melo - Universidade Federal do Rio de Janeiro, Rio de Janeiro, Brasil \\ Vera Lopes Besset - Universidade Federal do Rio de Janeiro, Rio de Janeiro, Brasil \\ Pedro Paulo Bicalho - Universidade Federal do Rio de Janeiro, Rio de Janeiro, Brasil
}

\begin{abstract}
The technological and scientific advances have brought, in the context of public health policies, a relentless pursuit of the notion of well-being and the elimination of pain, a feeling which was not always conceived as an evil to be eradicated. Foucault, through the concept of biopolitics, indicated that actions from the medical domain were incorporated by the State in order to control the bodies, with the support of medicalization. Starting from a psychoanalytic approach - in which it is assumed that pain can fulfill a role for man as a speaking animal - we conclude that in cases of chronic pain, it is critical, before curing it, to understand its purpose and to seek singular solutions.

Keywords: pain, medicalization, biopolitics, Lacanian psychoanalysis
\end{abstract}

Biopolítica e Dor: Aproximações entre Foucault e a Psicanálise Lacaniana

\begin{abstract}
Resumo
Os avanços tecnocientíficos repercutiram, no âmbito da saúde pública, em uma busca incessante pelo bem-estar e eliminação da dor, que nem sempre foi concebida como um mal a ser extirpado. Foucault, por meio do conceito de biopolítica, indicou que as ações do âmbito da medicina foram incorporadas ao Estado para controlar os corpos com o respaldo da medicalização. Partindo de uma aproximação com a psicanálise, a partir da qual supõe-se que a dor pode cumprir uma função para o ser falante, conclui-se que, nos casos de dor crônica, é fundamental, antes de saná-la, entender a que serve e buscar saídas singulares.

Palavras-chave: dor, medicalização, biopolítica, psicanálise lacaniana
\end{abstract}

Biopolítica y Dolor: Aproximaciones entre Foucault y el Psicoanálisis Lacaniano

\begin{abstract}
Resumen
Los avances tecno-científicos repercutieron en el ámbito de la salud pública, en una búsqueda incesante por el bienestar y eliminación del dolor, que no siempre fue concebido como un mal a ser extirpado. Foucault, a través del concepto de biopolítica, indicó que las acciones del ámbito de medicina se incorporaron al Estado para controlar los cuerpos con el respaldo de la medicalización. Partiendo de una aproximación con el psicoanálisis, a partir del cual se supone que el dolor puede cumplir la función de ser el altavoz, se concluye que, en los casos de dolor crónico es fundamental antes de curarlo, entender para que sirve y buscar salidas singulares.

Palabras clave: dolor, medicalización, biopolítica, psicoanálisis lacaniana
\end{abstract}

Descartes's Discourse on Method (1986) left a legacy, a fertile scene for the building of modern scientific thought, one that favors reason as measure of all things. If up until this point the explanation of illnesses was entrusted to religion, now, due to Cartesian influence, man - divided into res cogitans and res extensa - became the object of study of medicine. Before this, medicine was responsible for studying the body (res extensa), while philosophy and religion were in charge of studying the mind (res cogitans).

Disease began to be studied and defined as a series of signs and symptoms with a precise course and evolution, while health was seen as the absence of illness, or life within the "silence of the organs", as stated by Lériche (1936). With the advance of increasingly sophisticated techniques and imaging methods, sight and measure became the preferred means of approaching body phenomena. According to Foucault (1963/2008), medicine removed the patient's speech and emphasized, in practice, the clinical eye of the physician, who holds the knowledge over diseases. Through first sight and non-verbal contact, the physician knows what the patient suffers from, since he already incorporated into this knowledge the precise signs and symptoms of the pathologies found in the body. The question asked to the sick is no longer "what do you have?" but rather "where does it hurt?" (Idem, p. XVI). For Foucault, this question places the pathology within the organ and offers brief information. Thus, the patient no longer talks about what is happening to him and pain is emphasized to the detriment of the subject, as a sign to indicate disease.

The definition of health based on disease as a reference persisted for a long time (Canguilem, 1966/2012). However, during the post-war period, which left 
devastating marks in Western culture, a favorable ground emerged for the reconstruction and creation of changes that sought to repair, or minimize, the effect of those impressions upon society. This had repercussions upon the discussions regarding the need for change in the understanding of what is health, especially after the definition given by the World Health Organization, in 1946, describing it as a complete state of physical, psychic and social well-being, and not just the absence of disease. Thus, began the construction of a new logic of approach towards health (World Health Organization [WHO], 1946).

From this point on, health began to be considered a good to be acquired by citizens, through the assistance of each government of Western society, to the extent in which the State started to be accountable for public health policies. According to Farhi Neto (2010), this is the case of biopolitics used as a means to control the bodies. Medicine was incorporated into the State in order to legislate and standardize healthy behaviors through changes in living habits, focusing on discussions regarding the promotion of health. By assimilating this model, citizens became the main caretakers of their own health.

In Brazil, the health surveillance model gave to every person the role of guardian in order to prevent the occurrence of illnesses. In this sense, the search for the unattainable ideal of a complete bio-psychosocial well-being began to be absorbed by the population. Health and happiness became consumption ideals (Freitas, 2003). In addition to the pursuit of this ideal of a healthy body, there was also a shift in the relation with pain, suffering and illness (Rocha, 1995). Free access to medication - seen as a consumer goods displayed on drugstore shelves and shopping malls - became a handy resource to remedy any sign of pain. However, pain was not always conceived as an evil to be eliminated.

A closer look into the historical evolution of the concept of pain allows us to observe that it is linked to several political and social contexts. Before the nineteenth century, pain was an instrument of atonement under the corrective logic of Christian morality, a divine intention that should be endured with full dedication and humbleness (Raper, 1953). In the legal sphere, pain was the preferred tool employed by sovereigns to punish and repress the transgressors of public order (Foucault, $1975 / 1987)$. If in the past pain had performed a religious and legal function, from this point on it became increasingly considered as an evil to be eradicated. With the advance of science and the discoveries in the field of pharmacology, the signs and symptoms of pathologies became the real enemies to be fought.

Morris (1998) states that medical approach towards pain as from the nineteenth century began to consider mostly the visible and measurable characteristics of the body. On the other hand, the "invisible pain", related to subjective variables, was little explored since it could not be explained in an organic background. Despite the definition of pain as "an unpleasant sensory and emotional experience associated with actual or potential tissue damage" (International Association for the Study of Pain [IASP], 2012) open the door for subjective pain-related aspects, we notice that such traits are many times disregarded by people suffering from chronic pain. The healing of pain using medication as a single therapeutic resource prevails to the detriment of subjective issues related to this particular form of suffering.

Far from questioning allopathy as a form of treatment and its importance for people enduring pain, what is being discussed here is the abuse of this resource as the only strategy to handle suffering. We agree with Laurent (2004) when he states that "today we are immersed in medication. It is ubiquitous in our field and has been disrupting clinical practice. It defines the ideas of efficacy and transforms medical institutions" (p. 32). Medicalization commands contemporary society and this has effects on the subjectivity of our time.

By taking into account the effects of medicalization in the production of subjectivities, the present study sought to establish a relation between the concepts of biopolitics and pain. It is important to stress that this article is an attempt to bring together Foucauldian formulations regarding the concept of biopolitics - which will be addressed later on - and Lacanian psychoanalysis, starting from some observations concerning the notion of pain.

\section{Biopolitics and Pain}

It was by studying the relations between politics and medicine, in the 1970s, that Foucault (1977/2012) formulated his first observations regarding the concept of biopolitics. The author stressed that the incorporation of the duties of medicine by the State and the establishment of medical authority resulted in the distinguished position of the physician. It is important to notice that Foucault defined the concept of politics from two standpoints: first, by considering the power relations between the State and the collective actions directed towards the State apparatus 
- labeled as macro-power; and second, by analyzing power relations between social groups and individual members of society. In the latter case, power relations are intertwined in a social network of micro-powers. According to Farhi Neto (2010): "this power mesh is comprised by several confrontations, by multiple combats of powers against powers, of bodies against bodies" (p. 26). This was the object of study that Foucault labeled as "anatomo-politics", the way in which "the body of men are politically invested; the study of power technologies that, in a single fashion, both model these bodies and turn them into the pillars of its enforcement" (Idem, p. 26).

Science, when it produces a discourse about the body and pain, gains legitimacy by society to control the bodies, defining, through medicine, the standards to be followed, a process Foucault refers to as disciplinary method (Farhi Neto, 2010). This way, medical power begins to model the body, performing a crucial role within anatomo-politics. When a certain criteria is defined as a standard to regulate the health of the population, the state-invested medical power participates in biopolitics (Farhi Neto, 2010).

Biopolitics is the political practice of controlling the bodies of the individuals. It is a process derived from capitalism and the state-ownership of medicine, which began to act in behalf of this control, standardizing and regulating physical and mental illnesses. It is important to clarify that biopolitics is not a particularity of medical practice, but corresponds to the standards that are reproduced across society. In addition to controlling diseases, these standards include practices of personal care and the overcoming of body limitations. To have a healthy and productive body became the measure of all things. According to Le Breton (2003):

\begin{abstract}
Self-management in the fashion of tecnè is not only the fact of relying heavily on psychopharmacology when faced with the tribulations or complexities of everyday existence, also revealing itself in other social practices: the general usage of vitamins, fortifiers, dietary supplements etc., the modeling of the form of the body (...). These practices are voluntary ways of self-production, of modeling personal identity (p. 66).
\end{abstract}

In order to make some observations concerning biopolitics we performed in this article a brief rundown on Discipline and Punish, since in this work Foucault (1975/1987) made some comments regarding pain. With the adoption of the genealogical method, Foucault $(1977 / 2012)$ assumed that history is full of variations and inconstancies, and rejected any continuity within human existence, regarding feelings or physiological laws. Any human condition is subject to historical contexts:

\section{Effective history distinguishes itself from the his- tory devised by historians by the fact that it does not rely in any constant: nothing in man - not even his body - is sufficiently fixed in order to understand other men and recognize oneself in them (Foucault, 1979/2012, p. 18).}

The genealogical method was established by Foucault during the study of modern prisons, when he emphasized the relation between power and knowledge. In addition, it was due to the birth of criminology, in the nineteenth century, that the author identified exactly the intertwining between these two terms, since it was in the modern prison that the ideal conditions for the development of a crime science emerged. It was within this space that the possibility to separate, catalogue and classify several types of criminal individuals appeared, therefore establishing the theoretical grounds that came to serve the enforcement of disciplinary power (Foucault, 1975/1987).

However, prison genealogy was not a method limited to such institutions. It was a device used by Foucault $(1975 / 1987)$ to analyze the modern context of power relations, since in the same circumstance in which fields such as criminology emerged, within the legal and penal contexts, in other instances of society similar practices to the prison standardization where developed, such as the classification and surveillance in the field of medicine.

Foucault (1975/1987) labeled these disciplinary practices as "political economies of the body" (p. 25). In this context, power was no longer enforced through practices that caused pain, such as tortures and public corporal punishments; in modern societies, it began to be enforced through a more subtle and invisible manner, employing a new instrument: discipline. When analyzing Foucauldian genealogy critique, Oksala (2011) states that:

\footnotetext{
The analysis of disciplinary power may deepen our understanding on how coercive practices performed by modern penal institutions operate with considerably different means and through a different rationality of those that sought purely punishment by pain. This effectively reveals the dual role of the current system: it seeks both to punish and to correct, thus, it blends legal and anthropological practices (p. 79).
} 
Disciplinary practices are mainly aimed towards the body; it is the privileged stage of power struggles. The docile and productive body is needed as an instrument of power; the workforce that governs modern economy demands that the body be potentially apt to produce, and because of this a whole series of scientific knowledge and technologies were developed to enable control, education and cure for the body (Idem).

As pain is concerned, it turned from preferred instrument of social control - in times before the nineteenth century, through public displays of torture and corporal punishment of criminals or the atonement of sins - into an obstacle for the proper functioning of the body-machine. Medicine, psychology and pedagogy were summoned to establish a productive order, curing pain, and excluding and marking individuals with pathological classifications. On the other hand, power does not only exclude, reprimand or hide, i.e. it is not purely negative. Power produces truths, technologies and methods, and, therefore, it is also positive.

These are essential conditions for the "proper functioning" of the body. The body, in order to become healthy and productive, needed to follow a series of rituals and practices imposed by scientific disciplines, which, in a single motion, began to subdue and strengthen it. Thus, it was disseminated, in the form of medical prescription, the duty of exercising the body, feeding it properly, cleansing it, and medicating it. A body - at the same time docile and productive - became the end result of what Foucault (1975/1987) calls "political anatomy", or “power mechanics" (p. 119).

According to the readings of Foucault, in biopolitics, this domestication of the body, i.e. this power mechanics, is not enforced by a macro-power: it is embodied within each individual in the form of discourses of well-being, health and safety. Vilas Boas (1993) linked this "training of the body" (p. 82) to what Freud (1930/2006), in Civilization and Its Discontents, referred to as the condition of civilization, i.e. the restriction of the pleasure principle. According to Freudian theory, in order to achieve the goal of living in civilization, man had to internalize social rules under the form of super-ego, one of the three components of the human psyche, as well as $i d$ and ego. However, the search for pleasure in civilization was not fully subjected to standards, and what was left of it causes some sort of uneasiness among individuals, one that needs to be addressed through educational and therapeutic measures.
According to Foucault (1975/1987), each subject is the carrier of social standards and at the same time he is his own watcher, something that reminds us of Bentham's Panopticon, a device used by the author to explain how incarcerated individuals are watched and incorporate the view of those who watch over them. In biopolitics, the individuals assimilate the standards dictated by medical power, which begins to regulate the bodies, and pain is subjected not only to classification, but to the intervention of medicine as an evil to be extinguished at all cost.

From psychoanalysis we can think of pain as a byproduct of the uneasiness in civilization and as an effect of the subject's exclusion from capitalism: there is no room for singularity (Uhr, 2014). In opposition to medical approach - which is concerned in diagnosing and eliminating pain, following its calling for diagnosis and treatment -psychoanalysis enables pain to fulfill a role in the life of each subject, requiring an understanding of its purpose and highlighting its subjective aspects (Besset, Gaspard, Doucet, Vera,s \& Cohen, 2010).

\section{Psychoanalysis and Pain: Some Observations}

Pain is a theme that appears since the early days of psychoanalysis (Freud, 1886-1899/2006). In certain moments of his theorization, Freud tried to understand pain-related mechanisms. In Inbibitions, Symptoms and Anxiety, the author (Freud, 1926/2006) made some observations regarding pain and considered that such feeling occurs when external stimuli inflict the periphery of the body, break the protective shield and begin to act as continuous drives. Freud also states that, when there is physical pain, a libidinal investment occurs upon the pain point, thus, the person in pain concentrates on this fact and loses the ability to invest in worldly objects, and thus, remains focused on his own suffering.

In this manner, since Freud, we can notice that physical pain in the talking human being is not exclusively biological, since it has a relation with subjectivity. When someone in pain is capable of shifting the narcissistic investment from the body towards external objects, for instance, the intensity of the pain may be decreased. This fact is evidenced in grief elaboration processes, when the person that is suffering begins to reinvest libido into the world and, little by little, has his suffering decreased (Freud, 1926/2006).

Psychoanalysis is a possible form of treatment for subjective pain-related aspects, a fact that can be observed in cases of chronic pain, for instance, where lesions many times persist even after being treated with 
the appropriate medication (Besset \& Brandão Junior, 2012; Barreto \& Besset, 2012). On the other hand, unlimited medicalization offers individuals immediate access to drugs as an object to tampon suffering. Beginning with Foucault, we can think that these are the consequences of standardized society, which began to regulate itself with the physical and mental standards determined by biopolitics (Escobar, 1991). In this context, society is not merely governed by law, but oriented by behavioral prescriptions, comprised of what are considered healthy lifestyles, as mentioned before.

It is interesting to note that shortly before this Foucauldian formulation appeared, Lacan (1972) theorized on the capitalist discourse and its effects. This discourse was described by the author as totally excluded from social bond, i.e. a contemporary substitute for the discourse of the master, and linked to access to immediate satisfaction by gadgets, objects of consumption that are also used as a way of concealing suffering.

According to Sinatra (1994), capitalism proved its triumph through the mass-production of goods, supplied to national and international markets through globalization, overcoming linguistic and ideological boundaries. The fetish value of merchandise demonstrates its mode of production and capitalist discourse generates a variation in the relation between subject and pleasure. The subject is "glued" to pleasure; the object of consumption is the immediate path towards satisfaction. In this context, medication is oftentimes seen as a ready-to-wear solution, capable of eliminating suffering and anesthetizing psychic pain.

By approaching this point of view to Foucauldian analysis, it is possible to assume that biopolitics is responsible for having certain effects upon the production of subjectivities. The subject is influenced by culture, by medicalization, however, we must consider that he is not exclusively determined by them. In this sense, the possibility of expressing his uneasiness through speech, in the bosom of a treatment that makes room for suffering, allows the subject to find and build possible exits.

When approaching symptoms in present-day, Besset, Brito, Dupim and Espinoza (2009) state that, when faced with this context, the subject becomes disoriented, and is embarrassed by his body, frequently seeing it as an object in the goods market. In this manner, the body, an object subject to ownership, is also something that may be won or lost. It is like an accessory, an attire. As put by Veras (2006):
It emerges as a new dimension for the classic philosophical question of "having" a body or "being" a body. In the era of gadgets, we can speak of the body as something that may be worn. Wearing a body and adjusting it to the being in front of the mirror ( $p$. 01).

It is up to each individual to find a singular solution, an attire that enables the construction of a self-image. Therefore, chronic pain, for instance, can present itself as a possible attire.

In some cases, chronic pain may exert a role in the life of the subject. When dealing with this complaint it is necessary to have prudence on the direction given to the treatment. According to Besset and Brandão Junior (2012), differential diagnosis is an essential condition to "support the subject's enunciation in his attempt of building a personal theory for his chronic pain" (p. 445). In this manner, treatment is possible, respecting the case by case perspective, a quintessential process in psychoanalysis.

Sonia is diagnosed with fibromyalgia and attends a research and treatment facility for patients with chronic pain established by a research and intervention project (Besset, 2011-2014). She receives medical treatment, has weekly meetings with a psychologist and attends a Speech Group, a monthly meeting coordinated by a psychologist and a physician (Brandão Júnior, \& Carvalho, 2012; Brandão Junior, 2015). On a certain occasion, when describing having lived fourteen days pain-free - something the patient noticed by the amount of medication she stopped taking - she adds: "The things that Dr. X (staff psychologist) says, stay... I leave thinking about them. I must say they hurt. You know why they hurt? Because they stick to us like pins..." (Besset, 2012).

Sonia's speech indicates that there was a shifting in pain, lodged in the form of pain in the body, to a symbolic field: word. Treatment made the pain talk, so to speak, and issues concerning motherhood and femininity could be formulated.

While medicalization seeks control and an alleged standardization through the elimination of pain, psychoanalysis subverts this order and takes the symptom as a metaphor of a subjective uneasiness. In the treatment of people suffering from chronic pain it is necessary to perform manoeuvers that enable the subject to find a singular solution, shifting something in the unity established with his pleasure. In order to do so, it is understood that the role of the analyst is not mistaken with the one that holds knowledge over the bodies to discipline them. Psychoanalysis keeps the invention of 
the subject in the horizon, because it understands that each one knows about what is happening to them and can elaborate a solution from that.

\section{Conclusion}

In face of what was discussed, it is important to consider the role of psychoanalysis when summoned to answer for the treatment of pain. First, it is necessary to stress the importance of working alongside medical treatment, since we are frequently dealing with people suffering from unbearable pain. Second, it is necessary to be cautious and to respect the uniqueness of each case, keeping in mind that medication should not tampon subjective suffering.

On the other hand, this article considered that Foucault's contributions are essential in understanding that biopolitics are not only linked to the State, but introjected into subjectivity, as people incorporate the eye that watches over them and begin to control uneasiness by searching for immediate answers (Escobar, 1991). When subjugated by the effects of medicalization, they cease to exist as subjects.

Psychoanalysis contributes when it holds individuals accountable for their choices and offers them the possibility of finding less mortifying exits or solutions. Clinical treatment with people suffering from chronic pain, therefore, should not be standardized. It is necessary to discuss clinical practice - which demands know-how when faced with manifestations of pleasure embodied in symptoms - without losing sight of theoretical principles, guided by the possibility of elaborating suffering through speech.

Finally, we noticed that certain formulations deduced from observations made by Lacan (1985/1998) during the final phase of his teachings - regarding the accountability of each subject in search for singular exits for his pain, symptom and suffering - come close to Foucauldian propositions. In this article we were especially concerned with the propositions regarding a solution to the uneasiness generated by the control enforced by biopolitics: the production of new forms of subjectivity, with the purpose of questioning iatrogenic imperatives imposed by culture.

\section{Referências}

Barreto, F. P., \& Besset, V. L. (2012). Um aporte psicanalítico para o tratamento da dor crônica. Revista
Polêmica, 11(3), 385-395. Retrieved from http:// www.e-publicacoes.uerj.br/index.php/polemica/ article/view/3729

Besset, V. L. (2011-2014), Corpo e dor: O desafio das dores crônicas - Módulo I e II. Projeto de Pesquisa-Intervenção. Apoio FAPERJ. Circulação restrita.

Besset, V. L. (2012). Feminino e fibromialgia: A solução da dor. Trabalho apresentado no XIX Encontro Brasileiro do Campo Freudiano. Mulheres de hoje: figuras do feminino no discurso analítico. Salvador, Bahia.

Besset, V. L., \& Brandão Junior (2012). Quando a dor faz corpo. Revista Borromeo 3, 433-449. Retrieved from http://www.e-publicacoes.uerj.br/index. $\mathrm{php} /$ polemica/index

Besset, V. L., Gaspard, J. L., Doucet, C., Veras, M., \& Cohen, R. H. P. (2010). Um nome para a dor: Fibromialgia. Revista Mal Estar e Subjetividade, 10(4), 1245-1270. Retrieved from http:// pepsic.bvsalud.org/scielo.php?script $=$ sci_ arttext\&pid $=$ S1518-61482010000400009\&lng $=\mathrm{p}$ t\&tlng=pt

Besset, V. L., Brito, B. P. M., Dupim, G. V., \& Espinoza, M. V. (2009). Corpo e sintoma na experiência analítica. In V. L. Besset \& H. F. Carneiro (Eds.). $A$ soberania da clínica na psicopatologia do cotidiano. Rio de Janeiro: Garamond.

Brandão Junior, P. M. C. (2015). Para além da dor, o corpo (Tese de doutorado não publicada). Programa de Pós Graduação do Instituto de Psicologia da Universidade Federal do Rio de Janeiro.

Brandão Junior, P. M. C., \& Carvalho, L. (2012). A dor como demanda de tratamento. Trabalho apresentado no V Congresso de Psicopatologia Fundamental Dietética, Corpo, Pathos. Fortaleza, Ceará.

Canguilem, G. (2012) O normal e o patológico ( $7^{\mathrm{a}} \mathrm{ed}$.). Rio de Janeiro: Forense Universitária. (Originalmente publicado em 1966).

Descartes, R. (1986). Philosophical writings. Cambridge: Cambridge University Press.

Escobar, C. H. (1991). Dossier Deleuze. Rio de Janeiro: Hólon.

Farhi Neto, L. (2010). Biopolitica: As formulações de Foucault. Florianópolis: Cidade Futura. 
Foucault, M. (2008). O nascimento da clínica. Rio de Janeiro: Forense Universitária. (Original publicado em 1963).

Foucault, M. (1987). Vigiar e punir: Nascimento da prisão. Petrópolis: Vozes (Original publicado em 1975).

Foucault, M. (2012). O nascimento da medicina social. Ditos e Escritos: Arte, Epistemologia, Filosofia e História da Medicina (Vol. VII). Rio de Janeiro: Forense Universitária (Original publicado em 1977).

Foucault, M. (2012). Microfísica do poder. Rio de Janeiro: Graal (Original publicado em 1979).

Freitas, C. M. (2003). A vigilância da saúde para a promoção da saúde. Promoção da Saúde: Conceitos, Reflexões, Tendências. Rio de Janeiro: FIOCRUZ.

Freud, S. (2006). Publicaciones prepsicoanalíticas y manuscritos inéditos. Em Obras Completas. Buenos Aires: Amorrortu editores, Vol I. (Original publicado em 1886-1899).

Freud, S. (2006). Inhibición, Síntoma y Angustia. In Obras Completas. Buenos Aires: Amorrortu editores, Vol. XX (Original publicado em 1926).

Freud, S. (2006). El malestar en la cultura. Em Obras Completas. Buenos Aires: Amorrortu editores, Vol. XXI (Original publicado em 1930).

International Association for the Study of Pain [IASP]. (2012). Pain. Retrieved from http://www.iasp-pain.org/AM/Template. cfm?Section=Pain_Definitions.

Lacan, J. (1972). Du discours psychanalytique. Conférence à l'université de Milan. Retrieved from http:// pagesperso-range.fr/espace.freud/topos/psycha/ psysem/italie.htm.

Lacan, J. (1998). Conferência em Genebra sobre o sintoma. Opção Lacaniana. Revista Brasileira Internacional de Psicanálise, 23, 6-16 (Original publicado em 1985).

Laurent, E. (2004). Como engolir a pílula? Ornicar. De Jacques Lacan a Lewis Carol. n 1. Rio de Janeiro: Jorge Zahar Ed.
Le Breton, D. (2003). Adeus ao corpo. Campinas: Papirus, 2003.

Lériche, R. (1936). Introduction générale: De la santé a la maladie; Le douleur dans les maladies; Oú va la Médicine? Encyclopédie française, VI.

Miller, J. A. (2003). O último ensino de Lacan, Opção Lacaniana. Revista Brasileira Internacional de Psicanálise, 35, 6-24.

Morris, D. B. (1998). An invisible history of pain: Early 19th-century britain and america. The Clinical Journal of Pain, 14(3),191-196. Retrieved from http:// www.ncbi.nlm.nih.gov/pubmed/9758067

Oksala, J. (2011). Como Ler Foucault. Rio de Janeiro: Zahar.

Organização Mundial da Saúde [OMS]. (1946). Constituição da Organização Mundial da Saúde (WHO). Nova Iorque.

Raper, H. R. (1953). El hombre contra el dolor: historia de la anestesia. Barcelona: Salvat Editoraes.

Rocha, E. (1995). A sociedade do sonbo: Comunicação, cultura e consumo. Rio de Janeiro: Editora Mauad.

Sinatra, E. S. (1994). Variantes del argumento ontológico en la modernidad. In Sujeto, goce y Modernidad - Los Fundamentos de La clínica. Atuel. Buenos Aires: Actuel TyA.

Uhr, D. (2014). O apagamento do sujeito na clínica contemporânea: O exemplo da psiquiatria biológica. Rio de Janeiro, 162 páginas (Tese de doutorado). Departamento de Psicologia. Pontifícia Universidade Católica do Rio de Janeiro.

Veras, M. (2006). Dismorfofóbico. Letra Clínica, revista da Escola Brasileira de Psicanálise/seção Pernambuco, 1, 97-102.

Vilas Boas, C. T. (1993). Para ler Michel Foucault. Ouro Preto: Imprensa Universitária da UFop.

Recebido em: 22/07/2014

Primeira reformulação em: 10/03/2015

Aprovado em: 06/04/2015 
Sobre os autores:

Carla Oliveira Fernandes é doutoranda em Psicologia pelo Programa de Pós-Graduação em Psicologia do Instituto de Psicologia da Universidade Federal do Rio de Janeiro (IP-UFRJ), mestre em Psicologia (IP-UFRJ/2014), especialista em Psicologia Clínica e Saúde Mental (UFBA/2010), especialista em Teoria da Psicanálise de Orientação Lacaniana pela Escola Bahiana de Medicina e Saúde Pública (2008), bolsista CAPES e membro do Núcleo de Pesquisa Clínica Psicanalítica (CLINP).

E-mail: fernandesocarla@gmail.com

Cláudio Cruz de Melo é mestre em Psicologia pelo Programa de Pós-Graduação em Psicologia do Instituto de Psicologia da Universidade Federal do Rio de Janeiro (IP-UFRJ/2013), especialista em Saúde Mental pela Faculdade de Medicina da Bahia (UFBA/2007), possui graduação em Psicologia pela Universidade Federal da Bahia (1997), professor da Faculdade Ruy Barbosa e membro do Núcleo de Pesquisa Clínica Psicanalítica.

E-mail: claudiocmelo2@yahoo.com.br

Vera Lopes Besset é doutora em Psicologia (Université de Paris V), professora do Programa de Pós-Graduação em Psicologia do Instituto de Psicologia da Universidade Federal do Rio de Janeiro (UFRJ), coordenadora do Núcleo de Pesquisa Clínica Psicanalítica (CLINP)-UFRJ, pesquisadora da Associação Universitária de Pesquisa em Psicopatologia Fundamental (AUPPF), psicanalista e membro da Escola Brasileira de Psicanálise e da Associação Mundial de Psicanálise.

E-mail: besset@terra.com.br

Pedro Paulo Gastalho de Bicalho é psicólogo, especialista em Psicologia Jurídica, mestre e doutor em Psicologia, professor associado do Instituto de Psicologia da Universidade Federal do Rio de Janeiro, vinculado aos Programas de Pós-Graduação em Psicologia e Pós-Graduação em Políticas Públicas em Direitos Humanos, bolsista de produtividade em pesquisa (CNPq) e jovem cientista do Nosso Estado (FAPERJ).

E-mail:ppbicalho@gmail.com

Contato com os autores:

Carla Oliveira Fernandes

Rua Dr. Pedro de Souza Pondé, no 77 apto 402, Jardim Apipema. Salvador-BA.

CEP: 40155-270 